\title{
Pengembangan Bahan Ajar Geometri Tiga Dimensi berdasarkan Lima Fase Model van Hiele untuk Menumbuhkembangkan Penalaran Visuospasial
}

\author{
Ronaldo Kho \\ Univeristas Cenderawasih \\ Email: ronaldoankho@gmail.com
}

\begin{abstract}
Abstrak. Masalah yang ditemukan pada penelitian pendahuluan adalah SOAP (siswa asli orang Papua) SMP yang berkemampuan matematika rendah dalam mengontruk bangun ruang tiga dimensi memiliki kemampuan penalaran visospasial yang rendah. Berdasarkan temuan tersebut perlu dilakukan kajian secara teoretis maupun empiris untuk pengembangan bahan ajar geometri tiga dimensi khususnya konstruksi bangun yang dapat menumbuhkembangkan penalaran visuospasial SOAP. Pengembangan bahan ajar ini didasarkan pada lima fase (yaitu fase informasi, fase orientasi, fase penjelasan, fase orientasi bebas, dan fase integrasi) dari Model van Hiele. Jenis penelitian yang digunakan adalah penelitian pengembangan (developmental research) dengan tujuan untuk menghasilkan bahan ajar yang valid meliputi RPP berbasis kurikulum 2013, buku guru, buku siswa, LAS (lembar aktivitas siswa), dan alat evaluasi penalaran visuospasial siswa. Hasil penelitian menunjukkan bahwan produk bahan ajar geometri tiga dimensi memenuhi kriteria valid secara teoretis dan praktis.
\end{abstract}

Kata kunci: bahan ajar, geometri, van Hiele, penalaran visuospasial

\section{PENDAHULUAN}

Penalaran visuospasial memainkan peranan penting dalam menyelesaikan masalah-masalah di bidang teknik, arsitektur, kedokteran, fisika, dan matematika, serta di bidang yang lain. Penalaran visuospasial [1] diartikan sebagai aktivitas mental yang berkenaan dengan penarikan simpulan terhadap informasi visuospasial objekobjek. Di bidang matematika, penalaran visuospasial merupakan bagian penting dalam memahami matematika dan juga merupakan kemampuan khusus menggunakan bayanganbayangan visual dan hubungan-hubungan visual dalam menyelesaikan masalah [2]. Salah satu materi geometri yang dapat digunakan untuk menumbuhkembangkan penalaran visuospasial siswa adalah geometri tiga dimensi.

Untuk menumbuhkembangkan kemampuan penalaran visuospasial siswa melalui pembelajaran geometri tiga dimensi, diperlukan strategi, pendekatan, metode, dan bahkan teori pembelajaran yang sesuai. Salah satu strategi yang dapat menumbuhkembangkan kemampuan penalaran visuospasial siswa dalam pembelajaran geometri tiga dimensi adalah penerapan teori van Hiele. Dalam teori van
Hiele, selain diperkenalkan lima jenjang berpikir geometris juga diperkenalkan lima fase pembelajaran. Kelima fase tersebut adalah fase informasi, fase orientasi, fase penjelasan, fase orientasi bebas, dan fase integrasi.

Hasil penelitian di lapangan [3], [4], dan [5], menunjukkan bahwa siswa mengalami kesulitan dalam belajar geometri. Kho menemukan bahwa SOAP (siswa asli orang Papua) jenjang SMP yang berkemampuan matematika rendah dalam mengkontruk bangun ruang tiga dimensi juga memiliki penalaran visospasial yang rendah [1].

Belum ada penelitian tentang pengembangan bahan ajar geometri tiga dimensi berdasarkan lima fase van Hiele untuk menumbuhkembangkan kemampuan penalaran visuospasial SOAP jenjang SMP di Propinsi Papua. Di lain sisi, komitmen pemerintah daerah Propinsi Papua berlandaskan otonomi khusus (otsus) di bidang pendidikan adalah menciptakan orang asli Papua (OAP) sebagai sumber daya manusia (SDM) yang handal untuk membangun Papua Baru yang berpikir kritis dan mandiri. 
Masalah penelitian adalah Bagaimanakah produk pengembangan bahan ajar geometri tiga berdasarkan lima fase van Hiele untuk menumbuhkembangkan kemampuan penalaran visuospasial siswa khususnya siswa orang asli Papua (SOAP) di SMP yang valid? Tujuan penelitian adalah menghasilkan bahan ajar geometri tiga dimensi yang pembelajarannya melalui lima fase dari Model van Hiele yang dapat menumbuhkembangkan kemampuan penlaran visuospasial SOAP jenjang SMP. Sedangkan manfaat dari penelitian adalah mmemberikan kontribusi dalam pengembangan teori pembelajaran geometri yang berbasis fasefase van Hiele untuk menumbuhkembangkan kemampuan penalaran siswa SMP.

Penalaran visuospasial [1] diartikan sebagai aktivitas mental yang berkenaan dengan penarikan simpulan terhadap informasi visuospasial objek-objek. Aktivitas mental yang terjadi pada proses penalaran visuospasial setelah menerima informasi tentang suatu objek adalah menganalisis informasi visual, mensintesis informasi visual dan menarik simpulan tentang bentuk akhir objek yang terbentuk. Menganalisis informasi visual dari suatu objek berarti melakukan pengamatan terhadap bagian-bagian dari objek, menentukan bagaimana satu bagian berkaitan spasial dengan bagian yang lain atau dengan keseluruhan struktur. Mensintesis informasi visual dari suatu objek berarti menjalin atau memadukan unsur-unsur dan keterkaitan spasial antar unsur untuk membentuk sebuah objek. Menarik simpulan tentang bentuk akhir objek yang terbentuk berarti melakukan tindakan secara mental untuk menentukan representasi internal objek (representasi objek yang masih dalam pikiran) yang terbentuk. Objek yang terbentuk mungkin direpresentasikan secara eksternal oleh siswa sebagai objek yang tepat dan benar, tetapi mungkin saja terjadi objek yang direpresentasikan itu tidak sempurna.

Salah satu materi geometri tiga dimensi yang dapat digunakan untuk menumbuhkembangkan kemampuan penalaran visuospatial siswa adalah mengkonstruk bentuk bangun ruang bila diketahui tiga buah skema pandangan yang tampak, yaitu pandangan dari depan, pandangan dari samping kanan, dan pandangan dari atas. Berikut ini adalah contoh masalah geometri tentang mengkonstruk bentuk bangun ruang bila diketahui tiga buah skema pandangan yang tampak. Diketahui tiga buah skema pandangan terhadap sebuah bangun ruang yang tersusun dari kubus-kubus satuan, yang tampak pada Gambar 1. Dengan memanfaatkan ketiga skema itu, gambarlah sebuah bangun ruang.

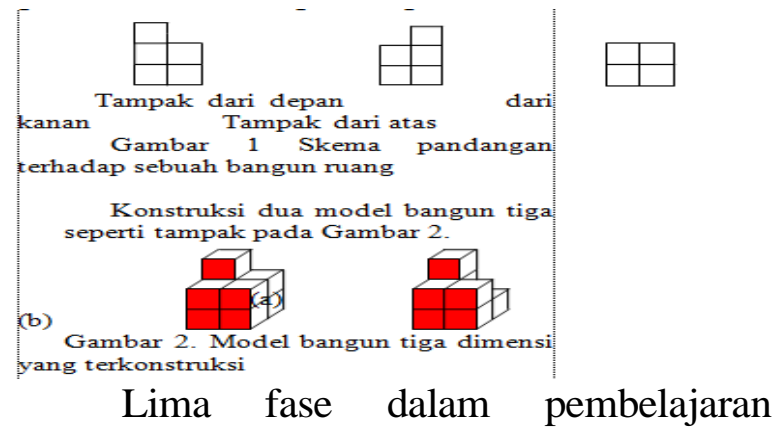
geometri menurut van Hiele [6] adalah sebagai berikut.

Fase 1: Informasi

Pada awal tingkat ini, guru dan siswa menggunakan tanya-jawab dan kegiatan tentang objek-objek yang dipelajari pada tahap berpikir siswa. Dalam hal ini objek yang dipelajari adalah sifat komponen dan hubungan antar komponen bangun-bangun geometri. Guru mengajukan pertanyaan kepada siswa sambil melakukan observasi.

Fase 2: Orientasi

Siswa menggali topik yang dipelajari melalui alat-alat yang dengan cermat telah disiapkan guru. Aktivitas ini akan berangsur-angsur menampakkan kepada siswa struktur yang memberi ciri-ciri sifat komponen dan hubungan antar komponen suatu bangun geometri. Alat atau pun bahan dirancang menjadi tugas pendek sehingga dapat mendatangkan respon khusus.

Fase 3: Penjelasan

Berdasarkan pengalaman sebelumnya, siswa menyatakan pandangan yang muncul mengenai struktur yang diobservasi. Di samping itu, untuk membantu siswa menggunakan bahasa yang tepat dan akurat, guru memberi bantuan seminimal 
mungkin. Hal tersebut berlangsung sampai sistem hubungan pada tahap berpikir mulai tampak nyata.

Fase 4: Orientasi Bebas

Berdasarkan pengalaman sebelumnya, siswa menyatakan pandangan yang muncul mengenai struktur yang diobservasi. Di samping itu, untuk membantu siswa menggunakan bahasa yang tepat dan akurat, guru memberi bantuan sesedikit mungkin. Hal tersebut berlangsung sampai sistem hubungan pada tahap berpikir mulai tampak nyata.

Fase 5: Integrasi

Siswa meninjau kembali dan meringkas apa yang telah dipelajari. Guru dapat membantu siswa dalam membuat sintesis ini dengan melengkapi survei secara global terhadap apa yang telah dipelajari. Hal ini penting, tetapi simpulan ini tidak menunjukkan sesuatu yang baru.

\section{METODE PENELITIAN}

Jenis penelitian adalah penelitian pengembangan model 3D, yaitu define, design, dan develop, dari model 4D produk Thiagarajan et al [7]. Define adalah kegiatan mengumpulkan berbagai informasi yang diperlukan (needs assessment). Design adalah kegiatan merancang produk awal atau draf program pembelajaran. Develop adalah kegiatan mengembangkan produk. Kegiatan penelitian tahun pertama dilakukan melalui tahapan sebagai berikut. Tahap pertama penelitian adalah melakukan studi pendahuluan (define atau needs assessment) yaitu mengumpulkan informasi yang diperlukan untuk perancangan draf pengembangan bahan ajar geometri tiga dimensi berdasarkan lima fase Model van Hiele untuk menumbuhkembangkan penalaran visuospasial SOAP jenjang SMP. Tahap kedua penelitian adalah perancangan (design) draf bahan ajar geometri tiga dimensi. Dalam perancangan tersebut dihasilkan rancangan RPP berbasis kurikulum 2013, buku guru, buku petunjuk guru, buku siswa, LAS (lembar aktivitas siswa), dan alat evaluasi penalaran visuospasial siswa. Tahap ketiga penelitian adalah pengembangan (develop) draf bahan ajar geometri tiga dimensi yaitu validasi kepada ahli dan diuji coba terbatas untuk mendapatkan penyempurnaan. Ujicoba bahan ajar dilaksanakan di kelas VIII SMP Negeri 6 Pariem.

\section{HASIL PENELITIAN}

Produk bahan ajar geometri tiga dimensi berdasarkan lima fase model van Hiele dihasilkan melalui penelitian pengembangan model 3D, meliputi:

1. Rencana Pelaksanaan Pembelajaran (RPP). Terdapat 2 RPP, yaitu RPP-01 terkait dengan mengonstruk skema pandangan bangun dan RPP-02 terkait dengan mengonstruk bangun tiga dimensi.

2. Buku Guru. Memuat kompetensi dasar, pengalaman belajar, langkah-langkah pembelajaran berdasar-kan lima fase van Hiele, teori lima fase van Hiele, dan teori penalaran visuospasial, serta kunci LAS dan soal latihan.

3. Buku Siswa. Memuat kompetensi dasar, pengalaman belajar, materi mengonstruk skema pandangan bangun dan materi mengonstruk bangun tiga dimensi, lembar aktivitas siswa (LAS), dan soal latihan.

4. Lembar Aktivitas Siswa (LAS). LAS untuk mengonstruk skema pandangan bangun terdiri atas 3, yaitu LAS. 1, LAS 2, dan LAS 3. LAS untuk mengonstruk bangun tiga dimensi terdiri atas LAS 1 dan LAS 2. 
Contoh LAS 2 pada kegiatan mengonstruk skema pandangan bangun sebagai berikut.

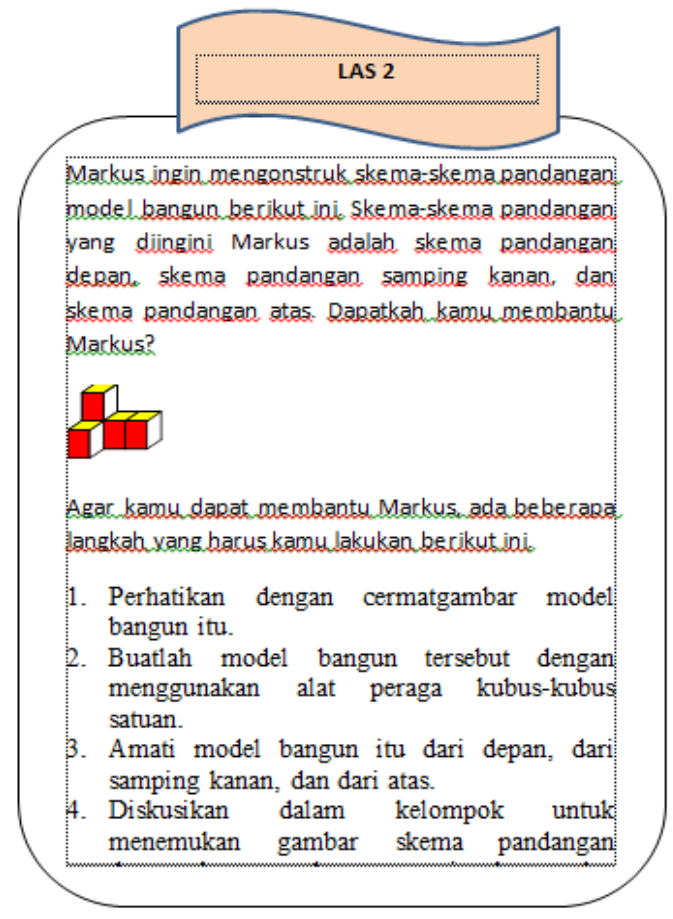

5. Instrumen Evaluasi Penalaran Visuospasial Siswa, merupakan instrumen yang digunakan untuk menilai kemampuan penalaran visuospasial siswa. Produk bahan ajar tersebut divalidasi secara teoretis oleh 3 ahli dan 3 praktisi) dan secara empiris diujicobakan terbatas di SMP Negeri 6 Pariem.

\section{PEMBAHASAN}

Produk bahan ajar dinyata valid oleh 3 ahli dan 3 praktisi dan layak untuk dipakai walaupun ada revisi kecil yang sarankan. Selanjutnya hasil ujicoba secara empiris di SMP Negeri 6 Pariem menunjukkan bahwa siswa mampu memahami materi yang diajarkan dan melakukan setiap suruhan dalam LAS (Lembar Aktivitas Siswa) dengan baik.
Berikut ini beberapa gambar kegiatan di kelas pada saat ujicoba.

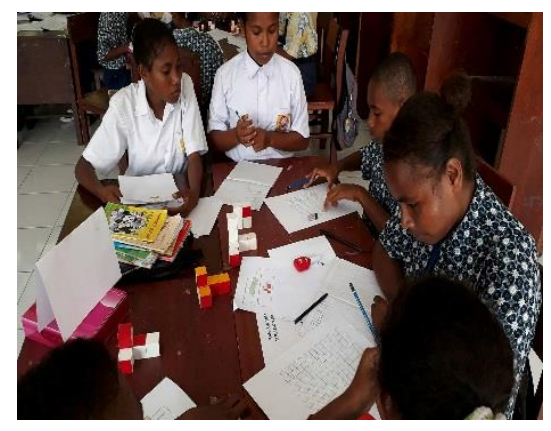

(a)
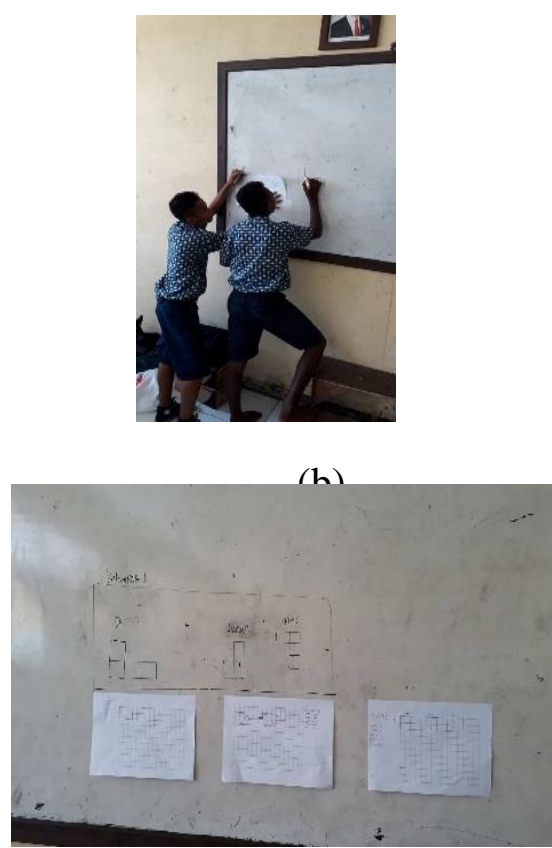

(c)

Keterangan gambar:

a. Diskusi dalam kelompok

b. Menampilkan hasil diskusi kelompok

c. Tampilan hasil diskusi 4 kelompok (I, II, III, dan IV)

\section{SIMPULAN DAN SARAN}

Berdasarkan hasil dan pembahasan, diperoleh simpulan sebagai berikut.

1. Produk bahan ajar geometri tiga dimensi yang dikembangkan memenuhi kriteria valid secara teoretis dan praktis.

2. Produk bahan ajar geometri tiga dimensi yang dikembangkan terdiri atas RPP, Buku Guru, Buku Siswa, LAS, dan Alat Evaluasi Penalaran Visuospasial Siswa.

Saran yang dapat dikemukakan sebagai berikut. 
1. Untuk mendapatkan produk bahan ajar geometri tiga dimensi yang memenuhi kriteria praktis dan efektif, perlu dilakukan ujicoba secara luas di lapangan.

2. Untuk menerapkan bahan ajar geometri tiga dimensi diperlukan guru yang terlatih dan menguasai materi bahan ajar, sehingga perlu ada pelatihan penguasaan bahan ajar geometri tiga dimensi bagi guru.

\section{DAFTAR PUSTAKA}

Kho, R. 2015. Jenjang Penalaran Visuospasial Siswa Berkemampuan Matematika Rendah dalam Mengkonstruksi Bangun Geometri Tiga Dimensi. Jurnal Ilmiah Matematika dan Pembelajarannya. Volume 1 Nomor 1.

Hunt, Earl 1995. The Role of Intelligence in Modern Society. The American

Scientist. Diakses

dari www.psych.utoronto.ca/ reingold/cours es /intelle gence/cache/Hunt-full.html, tanggal 11 Maret 2016.

Kho, R. 2009. Penalaran Visuospasial Siswa SMP dalam Menyelesaikan Masalah Geometri Berbantuan Alat Peraga Kubus Satuan. Seminar Nasional Matematika IV, Surabaya.

Sunardi. 2001. Hubungan antara Usia, Tingkat Berpikir dan Kemampuan Siswa dalam Geometri. Dalam prosiding Seminar Nasional Matematika "Peran Matematika Memasuki Milenium III". Jurusan Matematika FMIPA ITS Surabaya. Surabaya, 2 Nopember.

Sudarman. 2000. Pengembangan Paket Pembelajaran Berbantuan Komputer Materi Luas dan Keliling Segitiga untuk Kelas V Sekolah Dasar. Tesis tidak diterbitkan. Malang: PPS UM.

Kho, R. 1996. Tahap Berpikir dalam Belajar Geometri Siswa Kelas II SMP Negeri I Abepura di Jayapura Berpandu pada Model van Hiele. Tesis tidak diterbitkan. Malang: PPS IKIP Malang.

Thiagarajan, S., Semmel, D. S., \& Semmel, M. L. (1974). Instructional,

Development for Trainning Teacher of
Exceptional Children. Minnesota: Indiana University 